\title{
Narratives of Resistance in Trinidad's Calypso and Soca Music
}

\author{
Meagan A. Sylvester, UWI, St. Augustine \\ Trinidad and Tobago \\ drmasylvester@gmail.com or drmasylvester@hotmail.com
}

\begin{abstract}
In Trinidad, the historical, socio-political and economic conditions which gave rise to the birth of Calypso are usually highlighted, in the existing literature, however, there is very little information regarding the oppositional lyrics of current Soca songs. By concentrating on the praxis of cultural resistance exemplified in the narratives of selected Carnival, Calypso and Soca songs, this article expands the existing discourse. Trinidad's Carnival, post-emancipation, has important societal roles and functions. This article demonstrates that Carnival functions as performative rituals of resistance, individual and community awakening and identity development. Carnival's established roles, functions and rituals are deliberately designed to disrupt the status quo.
\end{abstract}

Keywords: Carnival, Calypso, Soca, Resistance, Respectability, Reputation

\section{Introduction}

Several synergies exist between the festival, the exuberant behaviours associated with the annual Carnival, and the art form of Calypso music and song. The respected, Trinidadian folklorist, J. D. Elder (1968), for example, states that the music and art of Trinidad and Tobago's Carnival (the premiere, national cultural festival), manifests publicly, the oppression of established economic and social systems. Elder's view concurs with that of Hill (2007), specifically, that social thought is illustrated visibly, in the communal and individual experiences that are demonstrated through sound. For Milla Riggio (2004), Carnival is an artistic institution in which music, song, dance, costumes, masks, handicraft, religion, poetry and sculpture depict the performers' and artists' creativity, worldviews, belief systems and philosophies of life. Further, Shannon Dudley, writing about Trinidad's culture and society, states that the performance and patronage of Carnival music help to articulate social identity (Dudley, 2004).

In this article, I address issues related to themes from Caribbean history, social anthropology and some aspects of social geography with regards to a discussion concerning Trinidad's Carnival and its accompanying, vibrant, Carnival music. Geographically, the Republic of Trinidad and Tobago constitute the most southerly islands of the tropical, Caribbean archipelago. Its history and resultant demography have been aided, abetted and facilitated by European colonization, enforced migration of African people and voluntary and involuntary migration of Western Europeans, Indians and Chinese people. Guilbault (2007) describes the socio-cultural and economic processes at work in the following terms: the presence of nonhomogenous migration cultures, the US hegemonic presence, and the myriad legacies of former colonial domination. 
In discussing the major characteristics of Carnival, Miles (1978), for instance, argues that Carnival is a creative construction... saturating and modifying cultural symbols and practices from the Caribbean. Cohen $(1980,1982)$ states that Carnival is a socially contested event in which there is political significance given the history and landscape in which it was created. I agree with Cohen's argument that Trinidad's Carnival while being representative of ritual and symbol and linked to a historic past, is not an autonomous, isolated event. Carnival is closely linked with the society and with the country's economic system. Its annual preparations have spawned several types of backward and forward industrial linkages. Carnival is influenced by the country's current political, economic, social and cultural contexts and conditions. Furthermore, I suggest that the accompanying Carnival musics, specifically, Calypso and Soca, embody elements of narratives of social and political resistance in their song lyrics. In Trinidad and Tobago, the cultural is not separate from the political. In fact, the culture of Carnival reflects traditions of the past while, simultaneously displaying the anti-hegemonic symbols of contestation and opposition.

\section{Trinidad's Carnival - The Street Activities}

According to Errol Hill (1972), Trinidad's Carnival can be described as the greatest annual theatrical spectacle of all time. The main activities for which it is famous are as follows: thousands of people parading in masquerade bands who play mas (in a fashion akin to that of the French Mardi Gras tradition); participants attending music concerts to hear the latest original music; enjoying the revelry of early morning J'ouvert ("playing mas" by adorning oneself with mud, paint and old clothes, and "jamming" voluntarily, in the early Monday, morning with a massive band of revellers); experiencing the annual Steelpan festival, Panorama; and attending high priced all-inclusive private fetes, at various locations all over the island. The current impressive spectacle, the lavish displays and activities of the festival are significantly different from the pre-abolition, Carnival celebrations. Before 1834, Trinidad's Carnival was celebrated exclusively by the white elite, particularly, by the French-speaking, Catholic, middle class (Pearse, 1956). Interestingly, enough, at that time, the black, enslaved people were spectators. Several researchers have stated that upon the abolition of slavery, the former enslaved people turned the tables and observations became mimicry of the elite. During the post-emancipation phases, the free black people, created and enacted their version of Carnival. In doing so, they transformed Carnival to become their own organic display of the "Carnival' tradition". Burton (1986) argues that from that point, Carnival began to depict social, political and racial tensions within Trinidadian society. This new space of contestation was an extension of the continuous, anti-hegemonic stance which existed between the enslaved people who opposed the overseers and plantation owners, during slavery.

In the 150 years leading up to political independence in Trinidad and Tobago, Carnival, a tradition from the earlier period of French rule, was a source of discomfort for the British colonial administration. Following the Canboulay Riots of 1881, the British colonial authorities enacted the Peace Ordinance in 1883, which banned all drumming in public places. This form of suppression of the organic culture of black people was the precursor to the development and creation of what I call narratives of resistance. Ironically, the ban on other drumming was used by black people to create musical instruments such as, the "tamboo bamboo" and "the Steeldrum". Accordingly, musical genres such as Calypso music and its later hybrid form of 
Soca music gained a foothold, as part of the contested forms of cultural expressions in Trinidad's Carnival experience.

Over the years, Carnival began to be transformed by African-Trinidadians. There was the unmasking of at least two poles of cultural activities which existed in the same festival. On the first pole, was the Mardi Gras tradition of the French, where "dress-up" and fantasy were celebrated. In its current appropriation, the term "pretty mas" (Carnival costumes made of skimpy bikinis, with feathers and beads) is reminiscent of the French, Mardi Gras tradition, and the annual, massive carnival celebrations in New Orleans, USA and Brazil. In the latter, two countries and in Trinidad, the inclusion of festive voyeurism has been growing in acceptance. The second pole of cultural activities, necessitated the re-imaging of the Canboulay tradition. On display is the drummology, the mud and paint daubed on one's body, and very importantly, the costumed mimicry of public figures. Such ridicule expresses the political and ideological conflicts between the haves and the have nots. The J'ouvert morning display on Carnival Monday, in Trinidad, is an opportunity to publicly express, one's dissatisfaction with the state. It is in marked contrast with the splendour of the costumes and pageantry of the "pretty mas" on Carnival Tuesday and the lavish spectacle of the earlier, Carnival King and Queen competitions.

\section{Trinidad's Carnival - Calypso Music}

Contextualising Calypso and its relationship to Carnival, Carol Boyce Davies (1985) asserts that Calypso music is created and performed as an integral part of the annual Carnival festivities. Giuseppe Sofo's (2014) perspective, complements Davies' (1985) views. Furthermore, he expands the notions when he links decolonization, culture, ritual, Carnival and identity. To him:

\section{The Carnival of Trinidad is a performative ritual of cultural resistance and awakening, claiming a space and celebrating freedom from any kind of oppression. The history of this ritual is strictly connected to the process of cultural decolonisation and political independence of the Caribbean country from the mother land; it is in Carnival and for Carnival that Trinidadians have successfully fought colonialism to gain their freedom. (Sofo, 2014, p. 17)}

Carnival and its accompanying Calypso music are inextricably interwoven and tied to identity development of the Afro-Trinidadians (Sofo, 2014; Davies, 1985; Liverpool, 2001). Given Trinidad and Tobago's diverse cultural, racial and ethnic demography, the history and the practice of Carnival has not been a totalising, monolithic representation of the national culture. Since the mid-twentieth century, the Afrocentric dominance of the Carnival tradition has assumed prominence and has overshadowed its earlier pre-abolition, Eurocentric, colonial roots.

\section{Expanding the Discourse: Action Research: Take 1}

My study has developed from participant observations over the last five years of the festival streets at Carnival celebrations. The process included face to face interviews and focus group sessions with a purposeful sample of respondents. My research has indicated that there is much more to Carnival than simply, the theatrical displays on the streets during J'ouvert and 'pretty mas'. The spectacle of the theatre, music, sounds and dance are demonstrations of forms of resistance. Since its nascent form during slavery, Calypso music, the main Carnival music in 
Trinidad, has acted as a purveyor of the society's morality through its songs (Sylvester, 2015). In the 2008 film, Calypso Dreams, David Rudder opines in a personal interview that Calypso music has traditionally fulfilled its role as a political and social lobby against the ruling directorate. Calypso has presented narratives of resistance in songs. Rudder agrees with (Rohlehr, 1990) concerning, the role of the Calypso art form. In fact, Calypso has been labelled 'the poor man's newspapers” (Calypsonian, “Brigo's” interview in Calypso Dreams, 2008).

For a long time, Calypso music has brought to the fore, critical societal issues. The four basic types of calypsos are namely: (i) political; (ii) social; (iii) humorous, and (iv) Extempo. The classification is based on the judges' criteria at the competitions. Political calypsos, the first type, speak to matters of the nation state. The calypsos concentrate on relations between the ruling directorate and the opposition. Examples of political Calypsos include: "Federation" by Sparrow, 1962; "PAYE" by Sparrow, 1958; "Better Days Are Coming" by Stalin, 1983; "Caribbean Man" by Stalin, 1979; "Three Bo Rats" by Cro Cro, 1988; and "Corruption in Common Entrance" by Cro, 1988. The second type, social calypsos address issues of the society's moral compass. "Yankees Gone" by Sparrow, 1956; "Rum and Coca Cola" by Invader, 1943; "Peddlars" by Lord Melody, 1958; "Better Days are coming” by Stalin, 1983; "Rain O Rama" by Kitchener,1973; "Life is a Stage" by Brother Valentino, 1972; and "Drunk and Disorderly" by Sparrow, 1972, are excellent examples of social calypsos. In humorous calypsos, the third type, texts are interconnected with both political and social commentaries. Masks of humour are used deliberately to cloak important messages. Songs such as "Steelband Clash" by Lord Blakie, 1954; "Freaking Streaking" by the Mighty Duke, 1980; "Mama Look ah Boo Boo" by Lord Melody, 1955; "Hold De Pussy" by Lord Blakie, 1970; as well as "Lackadoo" by Lord Funny, 2004, all exemplify types of Trinidadian humour. The art and skill of Extempo, the fourth type, "is a mystery" (as stated by Gypsy and The Pretender in the film Calypso Dreams, 2008). Further, both Calypsonians, indicate that they are unsure of how they achieved the skill. The Pretender, for example, indicates that: "I was like a human lexicon with words" (Interview, 2008). Gypsy explains that “....all I know is that when I was a child any time anybody ask me anything I used to respond in Extempo..." (Interview, 2008).

\section{Expanding the Discourse: Action Research: Take 2}

In 2016, I conducted a second series of interviews with members of the Calypso fraternity. Many suggested that the existing classification of Calypsos into four categories needs to be re-examined. This view was also expressed, in a radio interview, when the well-known Calypso researcher and archivist, Zeno Obi, concluded that all Calypsos can simultaneously be political, social and humourous (WACK Radio, 90.5 FM, February $15^{\text {th }}, 2016$ ). While every Calypsonian who performs can choose to lament or use humour, I agree with the view that the four discrete categories are no longer valid. As importantly, since the Calypso art form is a reflection of current issues, today's Calypsos do not conform to the four rigid, groupings of yesteryear (Interview, Zeno Obi, February 15 ${ }^{\text {th }}, 2016$ ).

\section{Trinidad Carnival - Soca Music}

Circa the late 1970s and early 1980s, with the advent of new beats in music coupled with the rise of digitized approaches to musical sound, Calypso music spawned a distinctive new type of Carnival music, namely, Soca music. It promised a new vibe, one which has a higher tempo, lighter lyrics and at the same time, is a more commercial sound (Sylvester, 2015) Together with 
its off-shoots of chutney soca, parang soca, groovy soca and ragga soca, the existing Calypso music began to fade as being the predominant, Carnival music. Instead, changing consumer tastes and market demand called for a "groovier" sounding expression. In my numerous interviews during the 2016 Carnival season, in Trinidad, I gleaned from participants' responses that Soca music has become Trinidad's premiere, party music. Many of my participants asserted that the lyrics of Soca music with offerings such as, "Party Done" by Angela and Machel Montano, 2015; "Ah Feeling" by Lead Pipe and Saddis, 2015; "Ola" by Olatunji, 2015; and "Phenomenal" by Benjai, 2015, all attest to Soca music's infectious nature. As importantly, Soca music simultaneously appeals to current, social behavioural patterns of debauchery, wanton-ness and excess. Given the significant shift in lyrics to become more explicit, it may seem odd to suggest that Soca music reflects similar political, social and cultural themes as its musical forefather, Calypso music. Nevertheless, my research suggests that Soca music, like Calypso music can illustrate important social and political issues such as, prosperity or poverty, economic depression, war, ethnic and racial rivalries and tensions, gender relations and orientation, demographic shifts, and culture wars. According to theorists Crouch (2007) and Lott (1995), the themes identified above, may shape the future course of the genre's musical evolution. I concur with the views posited by the two theorists. In this essay, I expand Crouch's (2007) and Lott's (1995) analyses. I suggest that (i) the Trinidadian reality, political, social and cultural contexts illustrate how Trinidadians use the two Carnival musical genres (specifically, Calypso and Soca), (ii) demonstrate their associated performance styles, as well as, (iii) present the narratives in the lyrics, in order to reinforce and retain their cultural heritage, and by extension, to (iv) inform their social identities. In many of the 2015 Carnival musical offerings, for example, an examination of the Soca lyrics reveals explicit, narratives of resistance.

\section{Narratives of Resistance in Soca's Lyrics}

The following discussion focuses on three popular hits from the 2015 Carnival, in order to illustrate some of the important issues discussed earlier. The songs are listed as follows: "Vagabond" by Ricardo Drue, "Ducking" by Fadda Fox, and "Lucy" by Destra (hyperlinks to the three videos are identified in the article's references). Generally, the songs' lyrics portray and resonate with narratives of resistance. Or in more academic terms, the songs depict the antitheses to established heteronormative and hegemonic societal tropes.

\section{Soca 1: “Vagabond" by Ricardo Drue}

The song's main narrative surrounds the concept of the vagabond who is an iconic, English, football, male supporter, associated with an unruly, angry mob. According to Pearson (1983) and Walvin (1986), references to hooligans and comparisons with soccer violence were once commonplace in the Football Association Cup Finals at Wembley, in England. In this analogy, the football supporters' behaviours are referred to as "an element of hooligan violence and vandalism familiar from other occasions". In the following verse, the chorus lyrics describe why someone with outrageous behaviour (jamming and wining) at Carnival, could be called a vagabond and/or a hooligan:

The way that ah jammin in de band

Deh callin me ah hooligan,

[Ah hooligan, ah hooligan]

Cultural and Pedagogical Inquiry, Fall 2019, 11(3), pp. 105-116

ISSN 1916-3460 @ 2019 University of Alberta

http://ejournals.library.ualberta.ca/index.php/cpi/index 
The way that ah wine on every gyal

Deh callin me ah vagabond,

[Ah vagabond, ah vagabond].

The descriptions hooligan and vagabond in the song, refer to the reveller at Carnival who is similar to the football supporter with his outrageous behaviour. In fact, such uninhibited misbehaviour, is not accepted and chided by the larger societies in Trinidad and England. The narrative of resistance demonstrated in this song can be seen in the "hooligan-like" behaviour which is the antithesis of respectable, middle class behaviour. Examples of Carnival misbehaviours are itemized in additional verses:

\section{Verse 1}

Ah doh even tek off meh shirt yet

Ah doh even roll on that tongue yet

Ah doh even wine on that gyal yet

[Gyal yuh callin we ah hooligan!]

Ah doh even drink out half ah de bar

Ah doh even push down no barrier

Ah wine on you, you cauh say ah cyahh

Yes I am ah vagabond,

Cause is whole dayy! We on ah mission

On de roah nah take no casual dayys!

We're vagabonds! Is priority tuh mash up de party,

[Those vagabonds] Nasty!

And we goin alll dayyy long!

Cause I'm ah vagabond!

From the song's lyrics, we have gleaned that the performer/singer deliberately juxtaposes his knowledge of conventional attitudes and behaviours "Ah doh even tek off meh shirt yet...Ah doh even roll on that ground yet....Ah doh even wine on that gyal yet" with the behaviours which he knows to be socially, unacceptable "We're vagabonds! Is priority tuh mash up de party, [Those vagabonds] Nasty! And we goin all dayyy long! Cause I'm ah vagabond!" Knowing the societally accepted behaviours, yet deliberately inciting persons to do the opposite, is indicative of an act of intentional resistance.

\section{Soca 2: “Ducking” by Fadda Fox}

Fadda Fox incites his listeners in the first verse of his song "Ducking" to consider the narratives of acceptable and unacceptable behaviour. He questions the demands which society places on its members and calls for "a ducking" or a breaking of the rules. He states that 
society's rules are often meant to be broken because they seemingly, lack good reasons to be obeyed:

\section{Verse 2}

Who does go tuh work on ah Thursday

Or even ah Fridaaayy?

When it have par-tayy-ay!

I, still put on my work clothes but I

Thirsty, to wine on dis shorty,

She tell me she up dehh,

Tell my supervisor I sick, have diarrhea

And I need to shoot,

I need tuh go to the pharmacy but I end up

In Fire de Wuk!

I well jump up and winin down, come tuh

Dress like ah hooligan,

When I turn around and see my boss in de place.

For the chorus below, Fadda Fox encourages his listeners to break the rules, abstain from work, and engage in "ducking" (hiding from wrong-doing),

\section{Chorus}

If yuh see meh duuuuuuuuckiinnnnnn

Ah doh wah my boss tuh see so I duuuuuucckinnnn

Doh want him tuh fire m so I duuuuuuuuckkinnnn

Pose tuh be in de pharmacyy, so I duuuuuuuuckinnnn Noooooooooooooowwww!

If you see me wine, wine, wine, wine, wine, wine And ah duckin jook, jook, jook, jook and I Duuuuuuuuuuuuuuuuuuuuckiiinnnnnnn!

If you see me wine, wine, wine, wine, wine, wine And ah duckin jook, jook, jook, jook and I Duuuuuuuuuuuuuuuuuuuckiiiiiiiiiiiiiiinnnnnnn!

In the lyrics, the narrative of resistance is made even clearer because the singer/performer itemizes the following strategies which would disrupt the typical, protestant work ethic. He: (i); questions the morality of showing up to work on two days before the weekend, (ii) pretends to be sick, in order to leave work, (iii) goes to a party in work clothes, and (iv) lies about his whereabouts, in order to protect his job. 


\section{Soca 3: “Lucy” by Destra}

The song "Lucy" (a deliberate pun) highlights a young teenage girl's decision to abandon her innocent days associated with childhood, for the uninhibited behaviour and revelry associated with Carnival. In the song, Lucy learns to confront the Carnival music's "jumbie" which takes an individual over during the Carnival season, and incites one "to get on bad", "misbehave", and "break the rules of society". In the opening verse Lucy states:

\section{Verse 1}

I grew up as ah real good girl, always home doh go nowhere,

Ah soon as I was introduce tuh Carnival Deh say I loose,

All down on de ground, wukkin, wukkin up Meh bottom,

And it draggin, draggin all Over town and deh say I Loose!

Was never ah partyier, my school bazaar I used tuh go,

But since ah was introduce tuh bacchanal Deh say I loose!

When ah drop it hot, and Ah winin, on top de speaker box and ah Grindin and ah doh wah tuh stop and deh Call meh Luucy!

I looser than, Lucy! I sweeter than, juicey!

Dis Carnival have meh so damn loose!

In her narrative of resistance, Destra calls on the Trinidadian audience to channel with her the experiences of being taken over by the "Carnival spirit, the jumbie". The Carnival jumbie has possessed her, and therefore, she should not be blamed for her uninhibited dancing.

\section{Cultures of Resistance}

To understand the culture of resistance demonstrated in Carnival music, one sees that two opposing roles and functions may occur, simultaneously. On the one hand, the festival functions to integrate the society, while on the other hand, it acts as a societal safety valve because during Carnival, expressions of protest, opposition and resistance are allowed. Abrahams (1983) and Wilson (1973), for example, both suggest that there are elements of a social geography of Carnival which are linked to a special form of cultural resistance with a distinctive spatial constitution. The concept spatial constitution has emerged from the sociology of space, a subdiscipline of sociology. Further, as posited by Urry (2004), sociology of space examines the social and material constitution of spaces. It is concerned with understanding the social practices, institutional forces, and material complexity of how humans and spaces interact. Furthermore, the concept supports some of the recent theoretical work developed in human, economic and feminist geography.

I agree with the perspectives of Abrahams (1983) and Wilson (1973) that in Carnival, there are issues of respectability and reputation at play. Further, that both issues are juxtaposed in the theatre, play and spectacle of the street displays and performances. Both issues are seen in the lyrics of the Carnival music. According to Wilson (1973), respectability is associated with a 
wide range of attitudes and behaviours such as: acting high class; behaving with sexual propriety; practising premarital chastity (for women); practising sober living (for men); demonstrating good manners; believing that the ideal nuclear family exists, and having church membership. Wilson furthermore, states that notions of respectability are part of the legacy of the colonial system of values. In addition, Burton (1997) asserts that the social system emphasizes marriage, the home, self-restraint, work, education and that it reinforces the existing, social hierarchy. The main institutions of respectability are the church and the school (Besson, 1993). Wilson interestingly notes that "... women are the strongest forces for respectability" (Wilson, 1973: 234). In contrast, issues of reputation are based on equality and notions of personal worth as opposed to respectability, which maintains the social hierarchy. Working within this conceptual framework, a man's reputation is determined by his sexual adventures, fatherhood, skills and experience (Besson, 1993). Further, it connotes success, admiration, achievement (for men), masculinity, virility, boasting, singing and the display of closely related sexual and verbal skills. In contrast, for women, reputation involves adhering to the perspectives of others and focuses on living for the public's acceptance. For men, demonstrations of their reputation are most obvious in their behaviours in rum shops and on the streets, namely, where crews of men tend to congregate.

To unpack the concepts of respectability and reputation by using the examples of the three Carnival songs by Antiguan, Ricardo Drue, Barbadian, Fadda Fox and Trinidadian, Destra, I note that through their lyrics, each musician has rejected conventional notions of acceptable behaviours, while they sought to re-define and re-interpret their own perspectives. In "Vagabond", Drue for example, encourages revellers to push past conventional, social norms, by throwing caution to the wind, and destroying respectable behaviour. In the second song, Fox in "Ducking", incites his listeners by describing narratives of resistance. He tells of his bravado when he challenged his supervisor at work, by directly flaunting his reputation, and in doing so, ignores the politics of respectability in the workplace. For Destra in "Lucy", the desire to not to continue to be respectable developed in her youth. Instead, her uninhibited behaviour is spurred on by a Carnival "jumbie". As a female performer, there is little care for the status of her reputation. She re-directs the blame from herself, to the exigencies of the Carnival's uninhibited behaviours.

\section{Conclusion}

Many culturally and racially diverse, societies like Trinidad and Tobago, have attempted to deal with the legacies of their colonial pasts. They grapple with issues surrounding decolonisation, and tussle with the continuing post-colonial realities and the associated selfexpressions. Through musical art forms, Trinidad and Tobago tackle some of these important issues (Sylvester, 2015). Indeed, the country boasts of the cultural, racial and ethnic richness and diversity of its demographic structure. In a similar manner to Trinidad and Tobago's affirmative responses to diversity, in the United States, the literature often includes reflections regarding ways in which African-Americans, other ethnic and racialized groups and members of the dominant society have responded to issues of diversity and inclusivity. Specifically, in his monograph, William Raussert (2000), asserts that jazz and blues have been used to represent social and cultural changes as well as historical, social and cultural times for individual AfricanAmericans and the larger, American community. A second scholar, Edwin Hill (2007), argues convincingly that while colonial conquest must focus on landscapes, colonial subjects must 
concentrate on soundscapes. Both authors argue that not only did the oppression of the colonial economic and social systems unintentionally, result in the transformation the types of musical genres which emerged, but that social thought and the communal and individual experiences and expressions of resistance were exemplified through the temporal state of sound. For example, in Trinidad resistance and opposition are manifested in Calypso and more recently, Soca. In the southern USA, Jazz, Rhythm and Blues, the internationally known, soul music, have emerged from the descendants of the former enslaved people.

To understand more fully, the rituals and performances that are associated with Trinidad's Carnival, I apply Hirsch's (1995) insightful perspective that the lived and visible landscapes are produced through everyday practices of spatial apartheid, and suggest that the transformative practices of organic displays are depicted in the mas (J'ouvert and pretty mas), and in the music. I suggest further, that in Carnival, Calypso and Soca music, there are at least two very important, interlinked forces at play (explicitly and implicitly); firstly, there occurs the deliberate subversion of the status quo, and secondly, the accepted, conventional, organised patterns of social behaviours are systematically, ridiculed and overturned.

By dint of a rite of passage, the country has emerged as a twin island republic with its specific and unique, globally known, musical and Carnivalesque cultures. Unintentionally, the oppressive colonial administration and its confrontation with the "drum culture" of the African population, the tumult that ensued with the resistance to the 1883 Peace Ordinance, the subsequent African organic responses to the attempts to "keep the order", all fostered the development of Calypso and a range of musical genres, as forms of popular opposition. The presence of the French derived and African-inspired Carnival celebrations laid the paths for citizens to use music as expressive forms of resistance and rebellion against the ruling directorate (Sylvester, 2015). By adopting Hirsch's concept of spatial apartheid, I acknowledge the stark dichotomies evident in the foreground and background of the societal landscapes, and have applied his views in this article, in order to understand the emergence of Trinidad's musical genres.

Impacts of Reputation and Respectability Politics in Trinidad's Music: Admittedly, this is not a perfect world, accordingly, man-made divisions exist within all societies, however, in the Caribbean the divisions are particularly stark and pronounced. There is competition between gender, race and social classes, each with its particular value systems and worldviews (Jones, 2015). My article explains ways in which issues of reputation and respectability are challenged in Calypso and Soca music. It is clear that within both musical genres that there has been a deliberate rejection of Eurocentric tropes. When applied to Trinidad and Tobago's contemporary cultures and everyday life, assumptions in colonial statutes, prescriptions, beliefs and attitudes, for example, that "whiteness is rightness", are disrupted. Furthermore, during Carnival, in music, J'ouvert and pretty mas, demonstrations of uninhibited behaviours have become increasingly acceptable. 


\section{References}

Abrahams, R. (1983). The Man of Words in the West Indies. Baltimore/London: Self-published.

Abrahams, R. D. (1982). The language of festivals: Celebrating the economy. In Turner, V. (Editor), Celebration: Studies in festivity and ritual. Washington, DC: Smithsonian Institution Press, 161-77.

Barrow, Christine. (1996). Family in the Caribbean: Themes and Perspectives. Kingston: Ian Randle Publishers Ltd.

Besson, Jean. (1993). Reputation and Respectability Reconsidered: A New Perspective on the AfroCaribbean Peasant Woman. In Women and Change in the Caribbean: A PanCaribbean Perspective, J. Momsen (Ed.), 15-37. Bloomington: Indiana University Press.

Boyce-Davies, C. (1985). The Politics of African Identification in Contemporary Calypso. Studies in Popular Culture, 8(2), Winter, 77-93.

Burton, Richard D. E. (1997). Afro-Creole: Power, Opposition, and Play in the Caribbean. Ithaca, NY: Cornell University Press.

Burton, M., \& Higley, J. (1987a). Invitation to elite theory: The basic contentions reconsidered. In G. W. Domhoff \& T. Dye (Eds.), Power Elites and Organizations (pp. 219-238). Beverly Hills: Sage.

Burton, M. G., \& Higley, J. (1987b). Elite settlements. American Sociological Review, 52, 295-307.

Cohen, A. (1982). A polyethnic London carnival as a contested cultural performance. Ethnic and Racial Studies, 5, 23-41.

Dudley, Shannon. 2004. Carnival Music in Trinidad: Experiencing Music, Expressing Culture. New York: Oxford University Press.

Elder, J. D. 1966. Evolution of the Traditional Calypso of Trinidad and Tobago: A Sociohistorical Analysis of Song Change Ph.D. Dissertation, University of Pennsylvania.

Elder, Jacob Delworth. (1968). The Male-Female Conflict in Calypso. Self-published.

Hill, E. C. (2007). Black Soundscapes, White Stages: The Meaning of Sound in the Black Francophone Atlantic. PhD Dissertation. University of Southern California, Los Angeles.

Hirsch, Eric. (1995). Landscape: Between Place and Space. In Eric Hirsch and Michael O'Hanlon (Editors), The Anthropology of Landscape: Perspectives on Place and Space (pp. 1-30). Oxford: Clarendon Press.

Hirsch, Arnold R., \& Logsdon, Joseph. (1992). Creole New Orleans: Race and Americanization. Baton Rouge: Louisiana State University Press.

Jones, Cecily. 2015. Shades of white: Gender, race, and slavery in the Caribbean. In Beyond Trafficking and Slavery. Online series: https://www.opendemocracy.net/en/beyondtrafficking-and-slavery/women-and-slavery-in-caribbean-whiteness-and-gilded-cage/ 
Lobbermann, Dorothea. (2003). Review of Negotiating Temporal Differences: Blues, Jazz and Narrativity in African American Culture, by Wilfried Raussert, 48(2), 275-277.

Lott, E. (1995). Love and Theft: Blackface Minstrelsy and the American Working Class. New York: Oxford University Press.

Pearse, A. (1956). Carnival in nineteenth century Trinidad. In Gerard Besson (Ed.), Trinidad Carnival (pp. 4-41). Port of Spain: Paria Publishing Co. Ltd. (A re-publication of the article in Caribbean Quarterly, 4(3\&4), 1956).

Pearson, G. (1983). Hooligan: A History of respectable fears. London and Basingstoke: Macmillan.

Raussert, W. (2000). Negotiating Temporal Differences. Blues, Jazz and Narrativity in African American Culture. American Studies - A Monograph Series, Vol. 87. Heidelberg: Winter.

Rohlehr, G. (1990). Calypso \& society in pre-independence Trinidad. Port of Spain, Trinidad: G. Rohlehr.

Sofo, G. (2014). Carnival, Memory and Identity. Kyлтура/Culture, (6), 17-23.

Stott, C. and Pearson, G. (2007). Football Hooliganism: Policing and the War on the English Disease. London: Pennant Books.

Urry, J. 2004. The Sociology of Space and Place. In The Blackwell Companion to Sociology, edited by Judith R. Blau (pp. 3-15). Malden, MA: Blackwell Publishing.

Walvin, J. (1994). The people's game. A social history of British football. London: Allen Lane.

Walvin, J. (1986). Football and the Decline of Britain. London: Macmillan.

Wilson, Peter. (1973). Crab Antics: A Caribbean Case Study of the Conflict Between Reputation and Respectability. Prospect Heights: Waveland Press Inc.

\section{Film, Radio Interviews and Discussions}

Dunn, Geoffrey, and Michael Horne. (2008). Calypso Dreams. Santa Cruz, CA: Geoffrey Dunn.

Radio Interview, Alongside Zeno Obi, on WACK 90.5FM, February 15 ${ }^{\text {th }}, 2016$.

Sylvester, Meagan A. (2015). Face to Face interviews and focus groups with ten (10). Calypsonians in Port-of-Spain, Trinidad, from April 1-15.

Sylvester, Meagan A. (2016). Face to Face interviews and focus groups with ten (10). Calypsonians in Port-of-Spain, Trinidad, from July 1-15.

\section{Discography}

"Ducking" by Fadda Fox: https://www.youtube.com/watch?v=2qunog47EVo

"Vagabond" by Ricardo Drue: https://www.youtube.com/watch?v=5KlCBRHpDxo

“Lucy by" Destra: https://www.youtube.com/watch?v=QZlbkTrqii0 